\title{
DIPTEREN II \\ NOTES ON SPECIES OF TABANUS FROM CERAM, WAIGIOU AND BURU \\ BY \\ GERTRUDE RICARDO.
}


PRAEDA ITINERIS

a L. F. de Beaufort in Archipelago indico facti

annis 1909-1910:

VII.

\section{Dipteren II \\ Notes on species of Tabanus from Ceram, Waigeu and Buru}

BY

GERTRUDE RICARDO.

The species collected by Mrs. L. F. de Beaufort while joining her husband on his voyage to Ceram and Waigeu, are included here, with one new species from Buru in the British Museum Coll.

Tabanus cohaerens Walker.

Proc. Linn. Soc. London, VIII, p. 188 (1865).

?.Atylotus picticornis Bigot, Mem. Soc. Zool. de France, V, p. $6 \% 1$ (1892).

Atylotus alfourensis Bigot, l.c. p. 672.

Two females from Ceram.

\section{Tabanus serus Walker.}

Proc. Linn. Soc. London, VI, p. 20 (1862).

Females from Waigeu.

\section{Tabanus obscuratus Walker.}

Proc. Linn. Soc. London, VIII, p. 232 (1864).

The species described by Doleschall as Tabanus furunculigenus (Natuurkund. Tijdschr. Nederl. Indië, XVII, p. 84, 1858) from Amboina, might be identical with this species judging from the description which however is too short and vague to make it possible to decide without seeing the type, he gives the size as only $9 \mathrm{~mm}$. and states the fly is extremely troublesome in the rainy season.

Type (female) and another female from N. Ceram. Walker speaks of one being perhaps a variety, having a broader abdomen and paler wings, this seems to apply to the one marked as the type; but as the second specimen is from Madame Pfeiffer's Coll. it could not be the type, as both specimens are the same species, the matter is not of importance.

There is a long series of females in Mrs. de Beaufort's Coll. from Ceram.

A medium sized and slender black species with brown wings distinguished from Tabanus recusans Wlk., by the absence of grey tomentum on the abdomen. Antennae and palpi reddish.

Forehead narrow. Length type $16 \mathrm{~mm}$. , others $15-16 \mathrm{~mm}$.

Face covered with yellowish brown tomentum, and with some short black pubescence. Palpi dull reddish, appearing black, covered with dense black pubescence, stout at base, ending in a long point. Beard brownish black. Antennae bright reddish, duskier at apex, and the first 
two joints yellowish with black hairs, the third joint with a very distinct tooth. Forehead with reddish brown tomentum, very. narrow and a third narrower anteriorly, about eight times as long as it is broad anteriorly. Frontal callus blackish, very narrow with a long raised-lineal extension. Thorax blackish brown with some greyish brown tomentum and with short black pubescence, sides and breast reddish brown with black hairs. Scutellum same as thorax. Abdomen deep black with black pubescence, a few pale hairs scattered on segmentations which on the under side are very narrowly pale. Legs black, the coxae and femora with some reddish brown tomentum, the pubescence black, fringe like on the posterior tibiae. Wings dark rich brown, pale at extreme apex and on posterior border at base, there are also pale streaks in the discal and other cells, sometimes in the submarginals, or in the posterior cells, there is' also one between the first and second longitudinal veins at base, veins brown. Wings in the type are paler.

Tabanus flavipennis $q$ n. sp.

Type $q$ and 3 other females from Bara, W. Buru, Moluccos, in Brit. Mus. Coll.

A robust wholly black species with a broad abdomen, and wings tinged yellowish on fore border becoming browner round the veins. Forehead narrow. Palpi long, very acute. Length of type $21 \mathrm{~mm}$, others $19-22 \mathrm{~mm}$.

Distinguished from Tabanus caerulescens Macq. by the absence of any red colour on the thorax or of any white pubescence on legs, all tibiae black.

Face and subcallus black, with some greyish tomentum and a reddish colour in parts, pubescence and beard blackish brown. Palpi long. with a very long slender point, the basal half slightly stouter, dull reddish, or reddish yellow, with black pubescence and some grey tomentum. Antennae blackish, the first two points dull reddish with thick black pubescence, the third joint black, in some of the specimens a little reddish at base, and in one as far as the small divisions, long, fairly broad at base, with a distinct tooth. Forehead narrow anteriorly, hardly more than half as wide as it is at vertex, about ten times as long as it is broad, black with some greyish tomentum, the frontal callus very narrow, hardly wider than its linear extension which is long and ends in a point; the callus might almost be described as one long narrow raised line, pointed towards the vertex, blackish brown, shining. Thorax, scutellum and abdomen dull black with black pubescence, finely punctuated, the pubescence recumbent, short and fairly thick, sides with longer black hairs, breast and underside of abdomen similar. Legs black, knees reddish, the pubescence black, hind tibiae with fringes of black hair on each side, tarsi with some bright red hairs below. Wings tinged yellowish brown, the costal border, extreme base and stigma yellow, all the other veins bordered with yellcwish brown and on fore border more largely so; in some of the specimens the yellowish brown tinge is spread over the wing, leaving it clear at extreme apex, and in centre of cells sometimes, veins brown, no appendix, all posterior cells widely open. Squamae brown, Halteres yellowish. 